\title{
The earliest villages in Iron Age Iberia (800-400 BC): a view from Cerro de San Vicente (Salamanca, Spain)
}

\author{
Antonio Blanco-González ${ }^{1}$, Cristina Alario García ${ }^{2}$ and Carlos Macarro Alcalde 3 \\ 1 Department of Prehistory, University of Salamanca, Salamanca, ES \\ ablancoglez@gmail.com \\ 2 Independent researcher, Salamanca, ES \\ cristinaalario@hotmail.com \\ 3 Town Planning Office, Council of Salamanca, ES \\ cmacarro@aytosalamanca.es
}

\begin{abstract}
The onset of the Iron Age underwent manifold disruptions. The emergence of longlasting nucleated villages in Iberia c. 900/800 BC best encapsulates such profound changes. This paper draws on the results of excavations over the last few decades at a fortified tell-like settlement in central Iberia: Cerro de San Vicente (Spain). The article focuses on formation dynamics in earth architecture to understand the role of cultural choices in the genesis of these sites. The occurrence of sophisticated lifestyles and novel cultural expressions in this village (avant-garde devices such as a drain pipe, unprecedented building techniques, exotic imports and alien practices) suggests the plausible role of inter-regional migration in their adoption. The appraisal of intra-site spatial arrangements sheds fresh light upon the diachronic social trajectories of these agrarian communities, from a seemingly egalitarian organisation to an increasingly ranked one.
\end{abstract}

KEY WORDS - household archaeology; earth architecture; archaeological excavation; Early Iron Age; Iberian peninsula

\section{Najstarejše železnodobne vasi na Iberskem polotoku (80o-40o pr.n.št.): pogled iz najdišča Cerro de San Vicente (Salamanca, Španija)}

IZVLEČEK - Za začetek železne dobe so značilne številne prekinitve. Pojav dolgotrajnih centralnih vasi na Iberskem polotoku v času ok. 900/800 pr.n.št. najbolje predstavlja te korenite spremembe. Osrednjo temo članka črpamo iz rezultatov izkopavanj preteklih desetletij iz utrjene naselbine tipa tell $v$ osrednjem delu Iberskega polotoka: Cerro de San Vicente (Španija). Za boljše razumevanje pomembnosti kulturnih izbir pri nastanku takšnih najdišč se v članku osredotočamo na dinamike oblikovanja arhitekture iz blatnih opek. Pojav naprednejših načinov bivanja in nove kulturne oblike (avantgardne naprave, kot so odtoki, edinstvene tehnike gradnje, eksotični importi in tuje navade) na tem najdišč nakazujejo, da so imele pri sprejemanju teh novosti verjetno pomembno vlogo medregionalne migracije. Ocena organizacije prostora znotraj najdišča pa kaže na diahronične družbene trajektorije teh poljedelskih skupnosti od navidezno egalitarne organizacije do vedno večje razslojenosti družbe.

KLJUČNE BESEDE - arheologija hišnih gospodarstev; arhitektura iz blatnih opek; arheološka izkopavanja; zgodnja železna doba; Iberski polotok 


\section{Introduction}

Iberia in the early first millennium BC was home to a variety of socio-political developments. However, research has traditionally focused on the historical trajectories of the Atlantic and Mediterranean areas under the direct impact of Phoenician colonisation and their immediate hinterland (Celestino, López Ruiz 2016). This emphasis has developed at the expense of further processes in inland and northern peninsular regions, within the so-called Indo-European-speaking peoples of 'Celtic' Iberia (AlmagroGorbea 1995; 2014). As a result, knowledge of the period is portrayed by some scholars as rather unbalanced (Moore, Armada 2011.23). This paper concentrates on the inner tablelands of central Iberia, far from the widely-researched coastal settings colonised by Phoenicians. In so doing, our work explores what new insights minority archaeologies can contribute to the characterisation of mainstream narratives on the Iron Age in Western Europe (Ruiz Zapatero 2011).

The early centuries of the first millennium BC in Iberia coincided with the later Bronze Age and the earlier Iron Age. The perception of the onset of the European Iron Age in terms of continuity or change depends heavily on chrono-cultural schemes, the scope and scale of analyses, and the kind of evidence they draw upon (Kristiansen 1998; Haselgrove, Pope 2007; Moore, Armada 2011). However, across Iberia, this period is mainly envisaged in terms of historical disruption. Several key phenomena occurred at this juncture, with variable regional and temporal currency: a) significant and steady demographic growth; b) abrupt shifts in lifestyles (e.g., the co-residence of neighbours in nucleated settlements) and ritual practices (e.g., the spread of cremation burial); c) a fluid transference and adoption of outsider know-how and technology (e.g., unprecedented earth-building techniques), imports (e.g., iron or wheel-thrown pottery), exogenous domestic animals (e.g., donkey, hen) and probably also people; and d) heterogeneous yet concomitant socio-political dynamics towards ranked organisations. These phenomena sharply contrast with previous millennia, when transcendental changes are far less apparent (Ruiz-Gálvez 1994; Fernández-Posse 1998; ÁlvarezSanchis 2000; Ruiz Zapatero 2009; Romero Carnicero et al. 2008; Torres Rodríguez 2013).

Among the aforementioned novelties, a crucial archaeological indicator epitomises the idiosyncrasy of the Iron Age in most Iberian regions: the founding of permanent sedentary villages (Almagro-Gorbea 1995; Parcero 2003; González Ruibal 2006-2007; Romero Carnicero et al. 2008; Delibes de Castro, Romero Carnicero, 2011; González García et al. 2011; Álvarez-Sanchis, Ruiz-Zapatero 2014). Understanding the emergence of these aggregated settlements is thus of paramount importance; however, current narratives are flawed by premises and longheld uncritical assumptions that permeate the literature. Thus, rural communities beyond the Mediterranean world are regarded as rather isolated and stagnant, transposing the much later ethnocentric GraecoRoman descriptions. The feasible interregional movement of people is dismissed by most Iberian scholars, who embrace a dogmatic autochthonism. Finally, a misunderstanding of the formation processes of the archaeological record leads to interpreting prehistoric remains (dwellings and necropolises) as the unproblematic and reliable reflection of prehistoric social life.

To furnish a more cogent account of social dynamics in Early Iron Age (henceforth EIA) Iberia (c. 800$400 \mathrm{BC}$ ), it is crucial to critically reconsider inherent limitations in the available sources, expose misguided stands, and raise new questions and fresh lines of enquiry. This article is intended to contribute to this endeavour by reappraising old archaeological evidence with new eyes, and by identifying prospective research avenues. The paper stems from an ongoing research project focused on a remarkably wellpreserved EIA hillfort in central Iberia: Cerro de San Vicente (Salamanca, Spain). Over the last decades this site has been subject to successive excavations, mostly within a preventive archaeology framework. The results were summarised in an outreach guide for the general public (Macarro, Alario 2012), but detailed information has remained unpublished, despite the relevance of some of the findings. A monograph with detailed documentation is to be published in 2018. For the time being, this article presents some outstanding discoveries at this site and discusses their contribution to scholarly debates on the emergence of nucleated settlements in Iron Age Iberia. This will help to pinpoint recent issues that will be tackled by forthcoming excavations at the site.

\section{The site of Cerro de San Vicente (Salamanca, Spain)}

\section{Location}

Cerro de San Vicente is a hilly relief in the city of Salamanca (Spain) by the Tormes River, a tributary stream of the Duero River and within the buffer 
zone inscribed in the UNESCO World Heritage List. The EIA occupations are located on an elongated and flat-topped sandstone plateau, situated at $805 \mathrm{~m}$ a.s.l. (Fig. 1-2). This hilltop settlement is delimited by three slopes: the north-western and southern are the steepest, namely the vertical cliff to the south, where the Tormes flows some $30 \mathrm{~m}$ below (Fig. 2). To the east, a smooth hillside - nowadays terraced - exends down to the La Palma thalweg, a ravine-like area drained in modern times, yet providing fresh water and suitable soils for horticulture back in later prehistory. To the northeast, a more easily passable plain was fortified with a rampart enclosing an area of 1.6ha. Outside the wall, further EIA remains have also been documented in this sector, so that the village covered an area over at least 2.5ha (Macarro, Alario 2012). The inhabitants of this village probably sought a place that was easily defended, located by the major river in this region and not far from the sedimentary lowlands, and at a strategic crossroads within long-distance exchange routes. Indeed, at this section of the Tormes River there was an important natural ford, subsequently crossed by the Roman road called Iter ab Emerita Asturicam (Roldán Hervás 2007), which has a Roman bridge 400m away from Cerro de San

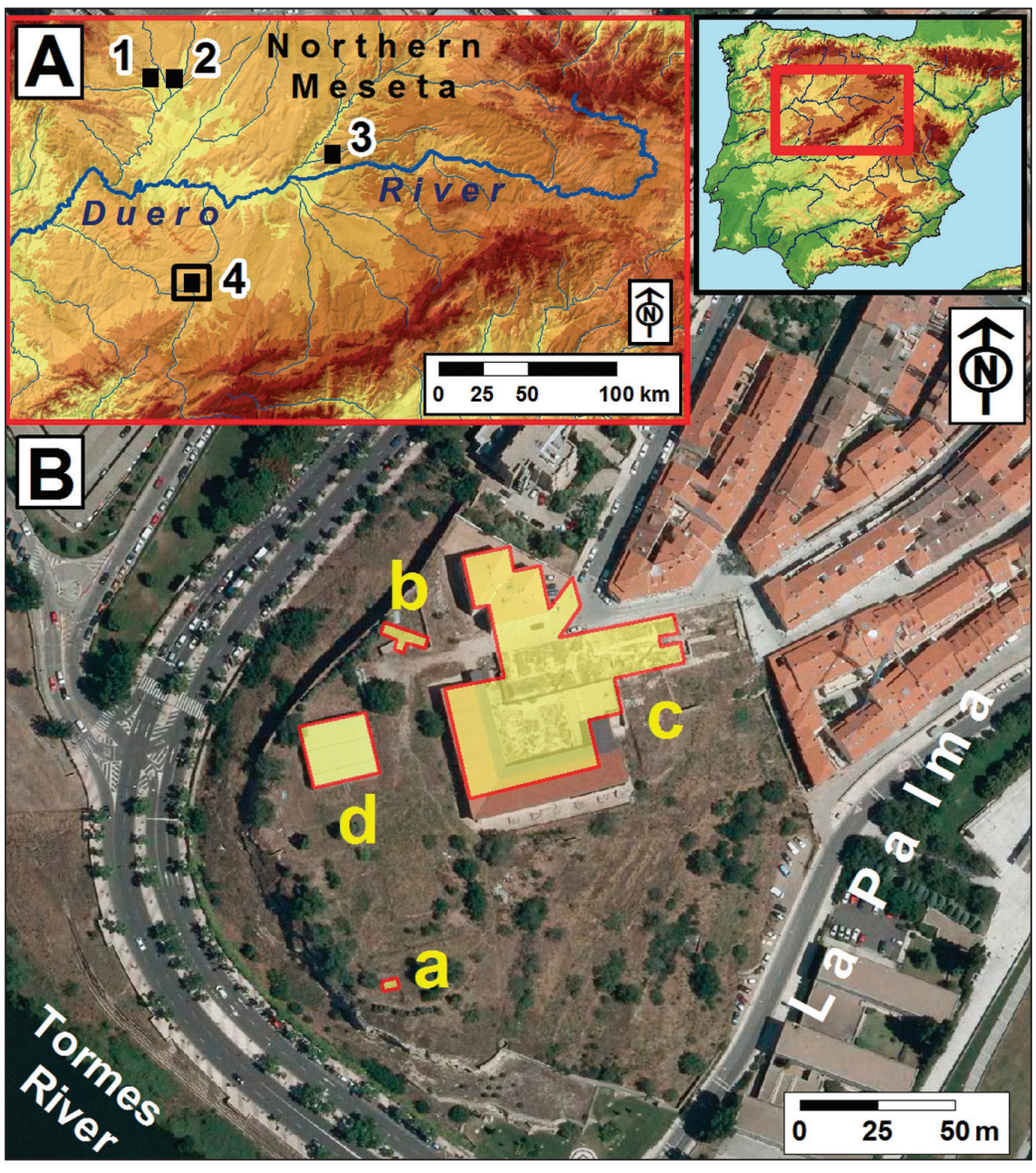

Fig. 1. Location of Cerro de San Vicente site in the Iberian peninsula. A Sites mentioned in text: 1 Los Cuestos de la Estación; 2 La Corona/ El Pesadero; 3 Soto de Medinilla; 4 Cerro de San Vicente. B Excavated sectors with EIA remains (in yellow): a test-pit in 1990; b trench in 1992; $c$ excavations in the cloister and surroundings (1994-2007); $d$ open-area excavations in 2006.

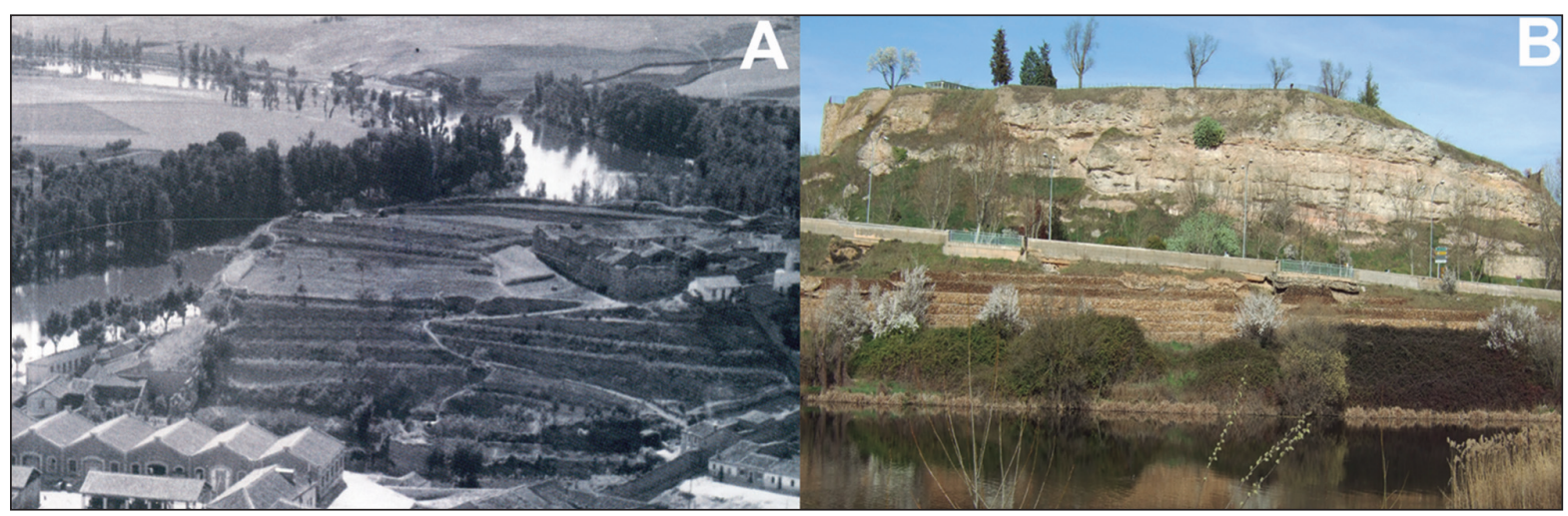

Fig. 2. A Cerro de San Vicente in the early twentieth century from the east, with the La Palma thalweg in the foreground, and the Tormes River in the background (photograph from the Gombau Archive, Council of Salamanca). B Present-day view from the south, with the Tormes in the foreground. Note the prehistoric mound protruding over the hill. 
After abandoning the EIA village, the summit was occupied by later Iron Age groups responsible for sparse disturbance of the uppermost levels. Fortunately, the subsequent urban expansion of Salamanca avoided the hillock - therefore preserving it from the deep subsoil truncation typical of Roman and medieval occupations - and it was neither cultivated nor scavenged to retrieve dark earth or bones for manuring. The place was only home to the high medieval and modern monastery of San Vicente and some contemporary buildings, which - except the foundation trenches - had a limited impact on the deepest prehistoric sediments (Benet Jordana 2001; Macarro, Alario 2012). EIA occupation was first identified by Prof. Maluquer de Motes (1951), and the settlement has been subject to modern excavations since 1990, which have until now unearthed about $30 \%$ of the site plan (Fig. 1B). In 1990, a 15m² test pit was dug close to the southern edge of the summit, leading to the first stratigraphic assessment. Between 1992 and 2007, successive large-scale excavations (some $1000 \mathrm{~m}^{2}$ ) were conducted in the northeastern plain, focused on the medieval and modern remains of San Vicente monastery, yielding partially truncated EIA houses and some smaller structures. Farther north, outside the monastic complex, exca-

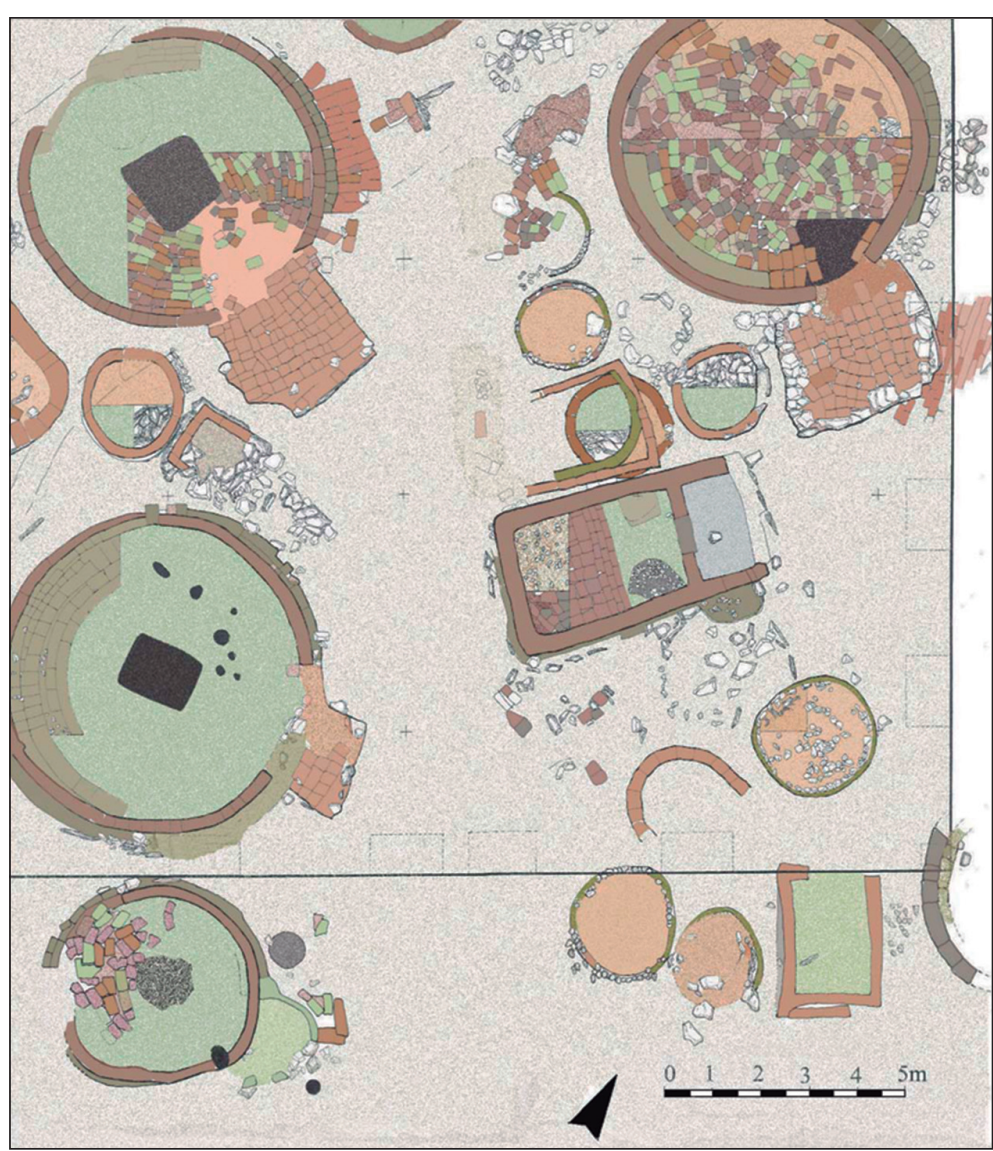

Fig. 3. Open-area excavations in 2006. vations in 1994-1996 and 2003 documented the prehistoric rampart (Macarro, Alario 2012). In 2006, a total of $500 \mathrm{~m}^{2}$ was uncovered in an open area, yielding five houses and 13 smaller ancillary structures dated to the later phases (Figs. 1B-3).

\section{Intra-site anatomy and biography of an EIA village}

Archaeological campaigns at Cerro de San Vicente have uncovered a thick and well-preserved prehistoric stratification up to 3-4m in height. As occurs at other contemporary sites (Romero Carnicero et al. 2008; Blanco García 2017), these sediments shape tell-like anthropogenic accumulations - an artificial mound covering the summit of the sandstone hill (Fig. 2). Such a sequence seems the cumulative result of occupation, refurbishment, ruination and abandonment episodes. These can be grouped into diverse phases - numbers depend on the excavated sector - composed of manifold layers and structures recorded as stratigraphic units (henceforth SU). Despite some unsolved uncertainties and mismatches between conventional chronology and radiocarbon estimates, an overall diachronic trajectory of the settlement can be presented, with four major phases (Tab. 1). Fieldwork has reached the deepest layers, especially in the test-pit excavated in 1990 and the medieval cloister excavated in 2001-2002. The earliest dwellings (phase I) were wooden huts, oval or circular in shape and covered with daub. These foundational layers yielded the first handmade painted wares and the earliest Soto-style vessels, a long-lasting pottery tradition characteristic of the EIA in the region (Romero Carnice$r o$ et al. 2008). The architecture and material culture from these oldest levels are accord with findings from the contemporary sites of Soto de Medinilla (Delibes de Castro et al. 1995) and Los Cuestos de la Estación (Esparza Arroyo et al. 2016) (Fig. 1A). There is more information on the latest, more extensively excavated phase III. Thus, an open-area excavation in 2006 uncovered such uppermost architectural structures, most of them now on public display (Fig. 3).

Eight radiocarbon assays are available from the site, which targeted 


\begin{tabular}{|c|c|c|c|}
\hline Phase & $\begin{array}{l}\text { Conventional chonological } \\
\text { framework }\end{array}$ & Architecture & Material culture \\
\hline Phase IV & Late Iron Age (400-50 BC) & $\begin{array}{l}\text { Poorly preserved domestic remains } \\
\text { on site. Some pits and quare stone } \\
\text { and mud houses. }\end{array}$ & $\begin{array}{l}\text { Wheel-thrown pottery, especially } \\
\text { painted Celtiberian ware. Plenty of } \\
\text { bronze and iron utensils. }\end{array}$ \\
\hline Phase III & $\begin{array}{l}\text { Early Iron Age } \\
(650 \mathrm{BC}-400 \mathrm{BC})\end{array}$ & $\begin{array}{l}\text { Heyday of the village. Thickly packed } \\
\text { and abundantly documented dwellings: } \\
\text { mud-brick roundhouses with porches } \\
\text { within stone-fenced domestic } \\
\text { compounds featuring sewers. }\end{array}$ & $\begin{array}{l}\text { Hand-made painted ware, late } \\
\text { Soto-style (aka 'Soto Pleno') ware, } \\
\text { early combed vessels, earliest wheel- } \\
\text { thrown imported vessels, Orien- } \\
\text { talising bronze and glass items. }\end{array}$ \\
\hline Phase II & $\begin{array}{l}\text { Onset of the Early Iron Age } \\
(800-650 \mathrm{BC})\end{array}$ & $\begin{array}{l}\text { Mud-brick round and square houses. } \\
\text { Settlement layout poorly known on site. }\end{array}$ & $\begin{array}{l}\text { Hand-made painted ware, plenty of } \\
\text { Soto-style ware. }\end{array}$ \\
\hline Phase I & $\begin{array}{l}\text { Late Bronze-Early Iron Age } \\
\text { transition (c. 1000-850 BC) }\end{array}$ & $\begin{array}{l}\text { Scattered post-built wattle-and-daub } \\
\text { round huts. Only isolated and partial } \\
\text { cases documented on site. }\end{array}$ & $\begin{array}{l}\text { Earliest hand-made painted ware, } \\
\text { earliest Soto-style (aka 'Soto Forma- } \\
\text { tivo') ware, bronze and early iron } \\
\text { items (imported?). }\end{array}$ \\
\hline
\end{tabular}

Tab. 1. Outline of key phases, associated architecture and material culture from Cerro de San Vicente.

both outdoor middens and indoor house fillings (Tab. 2). Some limitations are apparent. Thus, all samples are on long-lived charcoal remains and no AMS dates are available, only conventional radiocarbon estimates. The absence of taxonomic and taphonomic assessment impedes a fine-grained contextual evaluation, and thus, erratic anthracological residues redeposited in a younger layer or affected by the 'old wood' problem cannot be ruled out (e.g., Beta77445). The calibrated data 1 (Tab. 2) show the impact of the aforementioned pitfalls coupled with the effect of the plain area in the calibration curve $c$. $800-400$ cal BC or 'Hallstatt plateau' (Hamilton et al. 2015), since all these estimates fall within this time lapse. The foundation remains ill-defined; Beta77447 was retrieved from the bottom (phase I, SU 61) of a thick midden, but its wide standard deviation makes it unhelpful (Tab. 2). However, the internal coherence of radiometric dates and typology allow us to posit an early foundation, most likely by 850 cal BC (Tab. 2). Radiocarbon estimates from the latest layers (top zone of the sequence) from openarea excavations in 2006 suggest dates much older than those based on typological criteria alone, as often occurs (Hamilton et al. 2015). Thus, the occurrence of typical late Soto-style ware, early combedimpressed vessels, imported wheel-thrown vessels and bronze fibulae, and the general village layout, suggest a sixth century BC date (Tab. 1). However, an ashy layer covering the most recent floor of a longlived roundhouse from this phase III yielded burnt remains (CSIC-2072) actually dated to the eighth century BC with $83 \%$ probability (Tab. 2). The drainage pipe found in 1990 is among the oldest sewerage systems in the northern half of Iberia, yet its date is slippery: the previous phase III is badly-dated (Beta-77445) and the assay associated with phase IV (Beta-78721, c. 370-20 cal BC) is too recent and broad. Typology allows us to conclude that by 450 $\mathrm{BC}$ the whole population had deserted this village and moved to the nearby hills; only sporadic activities are traceable (Tab. 1). There they founded a large Late Iron Age hillfort that eventually became the Roman city of Salmantica (Benet Jordana 2001; Macarro, Alario 2012). Such relocation correlates with a marked and widespread social and political reorganisation after the mid-first millennium $\mathrm{BC}$ : previous scattered communities were driven by phenomena of aggregation (sinecism) that led to the foundation of larger oppida (Almagro-Gorbea 1995; 2014; Fernández-Posse 1998; Romero Carnicero et al. 2008; Torres Rodríguez 2013; Blanco García 2017). In sum, based on typological comparisons and radiocarbon dating, its biography spanned at least four centuries of uninterrupted occupation, which amount to some 16-18 generations. Obtaining accurate and reliable radiometric estimates of key milestones within this village's biography will be a priority in future fieldwork.

Extant material evidence for domestic activities is retrieved from two kinds of multi-layer accumulations informing diverse temporalities, like prehistoric tells elsewhere (e.g., Kienlin 2015; Shillito 2017): a) openair spaces, including lanes and refuse heaps (middens) where waste was routinely piled. Middens contain microstratified organic-rich ashy lenses with abundant domestic residues (ceramics, faunal bones,

1 Dates calibrated using Oxcal 4.2 with the IntCal13 curve (Reimer et al. 2013) and expressed at 2-sigma range. 


\begin{tabular}{|c|c|c|c|c|c|}
\hline Lab. code & Material & Context & Age BP & $\delta^{13} \mathrm{C} \%$ & Age cal BC $(2 \sigma)$ \\
\hline Beta-78721 & Charcoal & $\begin{array}{l}\text { 1990. Outdoor midden, top zone } \\
\text { (phase IV, SU 16). }\end{array}$ & $2150 \pm 60$ & -25 & $370-20$ \\
\hline Beta-77445 & Charcoal & $\begin{array}{l}\text { 1990. Outdoor midden, medium zone } \\
\text { (phase III, SU 30). }\end{array}$ & $2450 \pm 70$ & -25 & $700-380$ \\
\hline Beta-77447 & Charcoal & $\begin{array}{l}\text { 1990. Outdoor midden, bottom zone } \\
\text { (phase I, SU 61). }\end{array}$ & $2320 \pm 80$ & -25 & $\begin{array}{l}750-680(82.6 \%), \\
540-180(12.8 \%)\end{array}$ \\
\hline$\overline{C S I C-2072}$ & Charcoal & $\begin{array}{l}\text { 2006. Roundhouse 1, indoor conflagration } \\
\text { layer (phase IIla, SU 140b). }\end{array}$ & $2583 \pm 30$ & $-25.5 \pm 0.2$ & $\begin{array}{l}820-740(82.6 \%), \\
690-660(8.6 \%), \\
640-590(4.2 \%)\end{array}$ \\
\hline CSIC-2126 & Charcoal & $\begin{array}{l}\text { 2006. Roundhouse 5, indoor collapsed fill } \\
\text { (phase III, SU 521b). }\end{array}$ & $2541 \pm 39$ & $-25.0 \pm 0.2$ & $810-530$ \\
\hline Ua-34086 & Charcoal & $\begin{array}{l}\text { 2006. Outdoor midden by roundhouse } 4 \text {, } \\
\text { intermediate zone (phase III, SU 419). }\end{array}$ & $2535 \pm 40$ & -25 & $800-520$ \\
\hline Beta-98135 & Charcoal & $\begin{array}{l}\text { 1994-96, medieval cloister. Outdoor midden } \\
\text { layer (phase III, SU 87). }\end{array}$ & $2430 \pm 50$ & -25 & $760-400$ \\
\hline Beta-98136 & Charcoal & $\begin{array}{l}\text { 1994-96. Outdoor layer over collapsed } \\
\text { EIA rampart (phase II, SU 73). }\end{array}$ & $2290 \pm 80$ & -25 & $750-90$ \\
\hline
\end{tabular}

\section{Tab. 2. Radiocarbon dates from Cerro de San Vicente.}

botanical macro-remains, etc.) in secondary position, providing information on the everyday; and b) dwellings and ancillary buildings (workshops, granaries) in primary position, filled with indoor coarser strata composed of abundant rubble and architectural debris plus domestic residues that illustrate occasional episodes of construction, refurbishment or abandonment.

The overall layout for phase III (Tab. 1) is one of thickly-packed houses with ancillary smaller buildings, enclosed to the north by a stone-and-earth wall

(Fig. 4). Such edifices are solid, built with standardised materials, and exhibit regular shapes and sizes. The bulk of edifices adopt circular plans (Fig. 5A), the prevailing architectural choice in the region (Romero Carnicero et al. 2008.661-664; Ruiz Zapatero 2009.234-236; Blanco García 2017). Rectangular buildings also occur from phase II, and account for $25 \%$ of known edifices (Fig. 5B). Constructions can be divided into two groups: a) the largest ones are either roundhouses $\left(13-50 \mathrm{~m}^{2}\right)$ or rectilinear quarters $\left(11-25 \mathrm{~m}^{2}\right)$ and exhibit the diagnostic features of dwellings: central fireplaces, sometimes decorated, with traces of sooting and a continuous bench opposite the door by the internal part of the wall (Fig. $6 \mathrm{D})$; and b) smaller $\left(<7 \mathrm{~m}^{2}\right)$ circular or rectangular structures without hearths or benches, assumed to be barns - a round one yielded barley - ovens, workshops, kitchens or warehouses (Romero Carnicero et al. 2008; Álvarez-Sanchis, Ruiz Zapatero 2014). The circular houses in the late phases commonly have entrance halls, antechambers or porches tiled with mud-bricks, and some also feature perimeter sidewalks (Fig. 5A). Excavations through successive construction phases have shown that builders always orientated house entrances in strictly the same direction - commonly to the south-east - and that central fireplaces accurately overlaid previous ones.

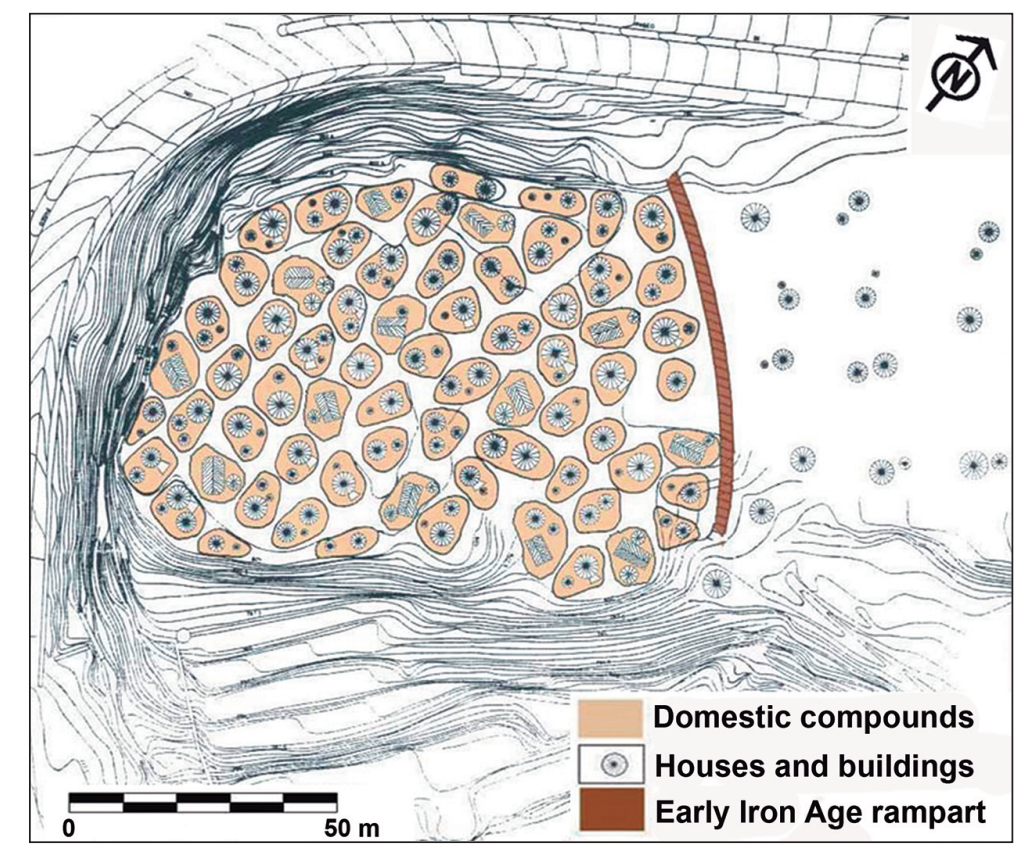

Fig. 4. Hypothetical image of the EIA prehistoric village of Cerro de San Vicente, based on archaeological investigations. 
In most cases, only the foundations of such edifices are in situ. In the case of dwellings, walls are $20-35 \mathrm{~cm}$ wide and up to $40 \mathrm{~cm}$ high, with exceptionally well-preserved walls up to $80 \mathrm{~cm}$ high (Fig. 6A). The builders used clay extensively, both for structural elements and to coat surfaces. Raw earth was commonly used in daub-and-wattle constructions, as in previous millennia. However, around $800 \mathrm{BC}$, novel materials appeared: sun-dried adobes of various formats, including parallelepiped and slightly
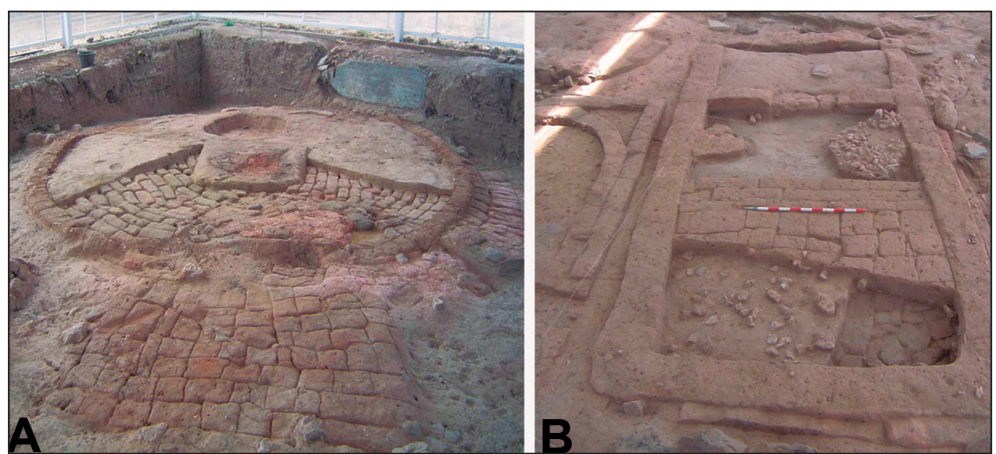

Fig. 5. Mud-brick architecture from the open-area excavations in 2006. A Roundhouse with tiled porch or antechamber; $B$ rectangular building with internal divisions. arched ones suitable for roundhouse walls (Fig. 6AB). Some rectilinear walls were built with solid earth mixed with straw (Fig. 6C). Iberian archaeologists often describe such walls rather vaguely as tapial or rammed earth, yet their building technique is ill-defined: they could be actual rammed earth, also named pisé de terre - mud filled and compacted using wooden formwork (Jaquin et al. 2008), or kneaded mud, also known as bauge or façonnage direct (Belarte 2002.40-41). In any case, these earth building techniques and know-how were unprecedented in inner Iberia prior to $c .850 \mathrm{BC}$ (Álvarez-Sanchis 2000; Romero Carnicero et al. 2008). All of the inner surfaces of the houses were plastered with clay, from floors to walls including hearths, and these mud coatings are often hardened by fire (Fig. 6D). The floors were carefully prepared with a succession of layers to guarantee perfect waterproofing and
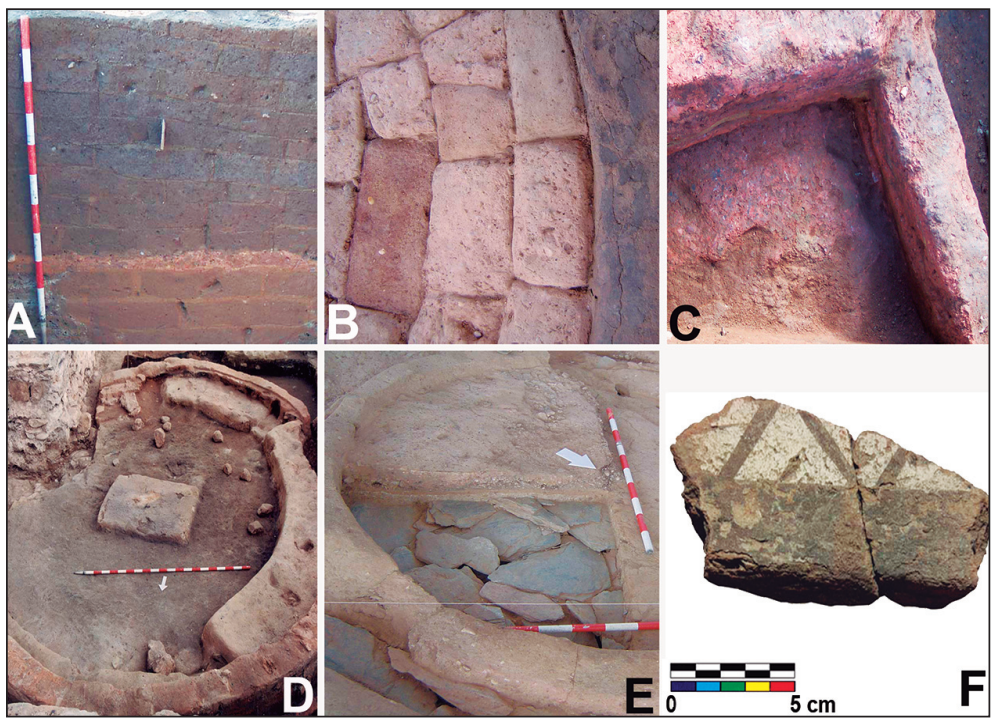

Fig. 6. Unprecedented EIA earth building materials. A wall made of rectangular mud bricks; B curved mud bricks; C rectilinear solid earth walls; D mud-plastered house, including a hearth and bench; E sectioned floor of a small round building showing superimposed layers; F black and white painted wall coating. smooth and hard soil surfaces. These involved slate slabs covered with gravel and an outer coating made of crushed sandstone mixed with sand and water (Fig. 6E) - an effective technique deploying local materials that was still in use in medieval times. On occasions, the bench and lowest walls exhibit brightly coloured plasters. These are predominantly monochrome geometric motifs (e.g., triangles in red or white), and also polychrome designs in red, yellow and black (Fig. 6F). The superimposition of plasterwork coats indicates the periodic renewal and refurbishment of the house. Indeed, phase IV of roundhouse 6 (from the 1990 test-pit) featured 17 soil micro- layers within a thick mud coating $13 \mathrm{~cm}$ thick.

The houses yielded no internal divisions. The only exception is a rectangular building divided into three rooms by a mud-brick partition and a raised floor, which may suggest functions other than residence (Fig. 5B). The roofing of these buildings remains a matter of speculation, since no clearly collapsed roofs have been identified. The presence of some central postholes and frequent lumps of daub featuring trunk imprints suggest thatched roofs, likely supported by a wooden structure and a central post.

As for formation dynamics, no equipment akin to 'de facto refuse' was clearly left behind inside the mentioned buildings (Schiffer 1987; LaMotta, Schiffer 1999). The widely and uncritically accepted 'Pompeii premise' was not in operation here, and this realisation prevents us from making any direct interpretations in utilitarian or social terms (LaMotta, Schiffer 1999). In actual 
fact, the demise of houses probably involved certain formalities (Webley 2007). Thus, dwellings and subsidiary structures seem to have been carefully cleared prior to their final abandonment. In addition, walls were dismantled, and house interiors infilled with carefully cached mud-bricks lying on their wider sides (Figs. 5, 7B). These strata of adobes were subsequently used as foundations for the succeeding house floor. Some houses were also burnt (Fig. 7), most probably on purpose, since the fire was really intense, i.e. fuelled to keep it burning; combustion only affected particular buildings and not their surroundings; and houses were devoid of any belongings or furnishings, i.e. they had been emptied in advance (cf. Stevanović 1997). The interment of individual children below house floors was also a widespread and long-lasting practice by Iron Age peoples in Iberia (Romero Carnicero et al. 2008; Sánchez Alonso 2015). This site has hitherto yielded only one such burial. In 2002, excavations of a roundhouse in the cloister revealed a neonate with articulated bones; this corpse was deposited within a small hole beneath the soil and lacked any burial furnishings.

The later phases of this village were internally arranged in domestic neighbourhoods or aggregates of buildings, each one probably used at the same time by a single household. Excavations in 1990 (Fig. 1B) unearthed parts of two roundhouses enclosed
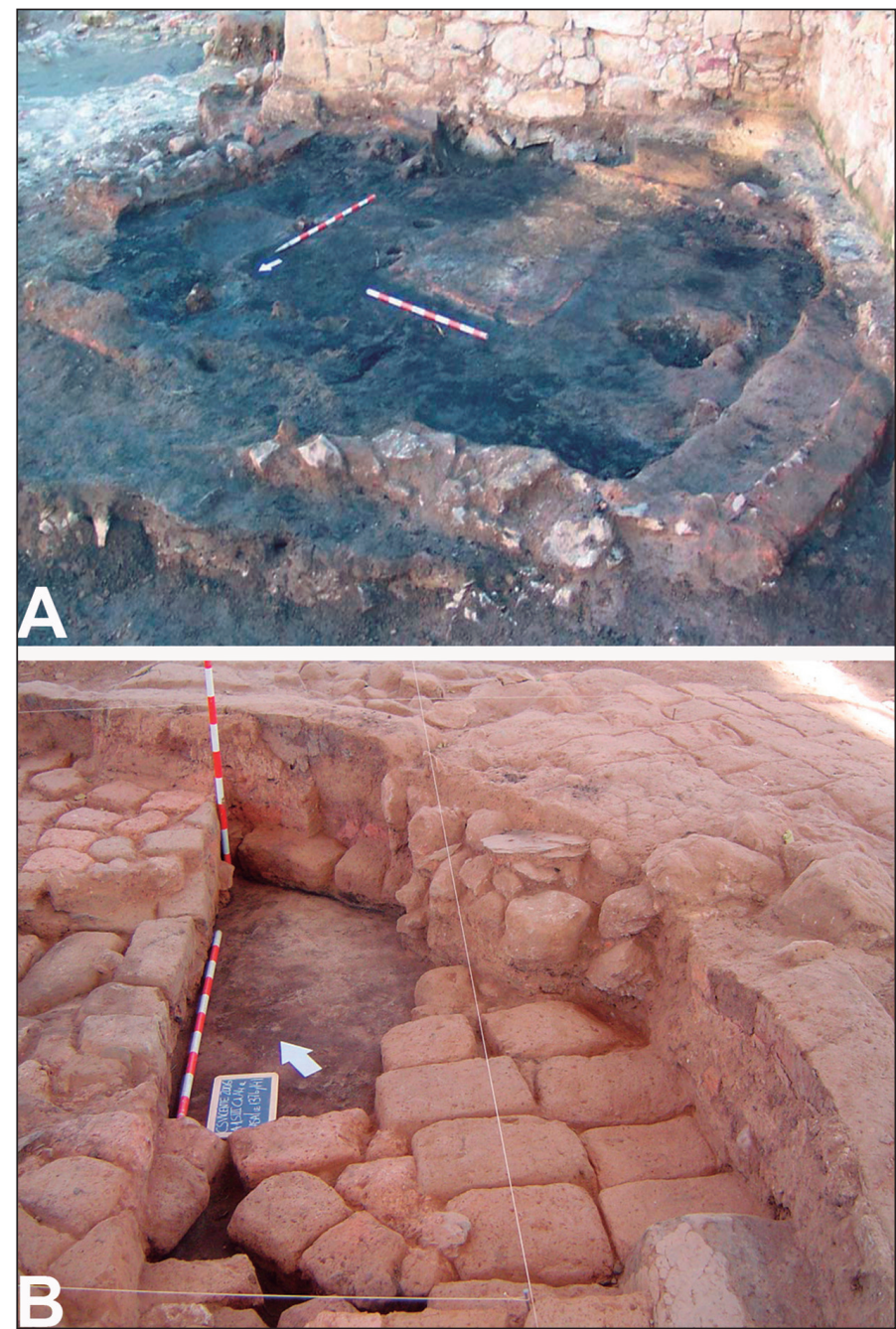

Fig. 7. Forms of house abandonment. A rectangular burnt building devoid of items (partially overlaid by medieval walls); B burnt roundhouse infilled with several layers of cached mud-bricks (sooting apparent on the floor, under the adobes). by a linear structure of large sandstone boulders, the probable foundation of a wooden fence that demarcated this compound from the adjacent one (Fig. 8). The courtyard around these houses was tiled with mud brick, which overlaid a slate drain pipe featuring two parallel walls covered by slate capstones (Fig. 8). Similar EIA sewer channels from southwest Iberia have been published (e.g., Rodríguez Díaz 2004), but this is the oldest and northernmost example known to date. These interspersed and fenced domestic clusters were connected by winding lanes (Fig. 4). Since the location of open-air spaces was reproduced through time, and constructions were rebuilt on the same spots, the earliest layouts and functional arrangements persisted for centuries.

Finally, it is worth mentioning the rampart in the north-eastern plain area (Figs. 4, 9). Despite its ex- tensive destruction by medieval and modern buildings, some $35 \mathrm{~m}$ of this massive enclosure were detected in four rescue excavations (1994-1996, 2003). The preserved remains are $3 \mathrm{~m}$ wide and up to $1.5 \mathrm{~m}$ in height, and originally some $90 \mathrm{~m}$ long. Its foundation was made with large slate slabs and sandstone boulders overlaid by earthen rubble framed by two mud walls, a rampart-building method documented in other EIA villages (e.g., Misiego et al. 2013).

\section{Material culture and village lifestyles}

The accumulation of archaeological remains at Cerro de San Vicente was heavily mediated by cultural precepts regulating how to dispose of refuse and how to abandon and rebuild living quarters. Everyday waste was routinely piled in open-air heaps in 
the surroundings of buildings. Indoor infills and mostly outdoor middens have produced abundant archaeological and bioarchaeological items. Yet these are redeposited residues in secondary position, i.e. items discarded out of their original 'systemic' context (LaMotta, Schiffer 1999). Bearing in mind such intricacies, the multi-stratified nature of these accumulations, coupled with typological comparisons and radiocarbon-dating, allow a diachronic overview of domestic equipment and everyday chores.

Excavations have retrieved a wide and rich array of archaeological materials. These people lived on integrated and complex agropastoral practices, based predominantly on wheat (Triticum aestivum/durum) combined with other minority cereals (Triticum dicoccum and Hordeum vulgare) and legumes (Vicia faba), suggesting a low-fallow agriculture system (Romero Carnicero, Cubero Corpas 1999; Romero Carnicero et al. 2008.664-668). Palynological analyses at the site indicate a dense and stable riparian forest, whereas the progressive clearance of arboreal taxa and the expansion of shrub and grassland (Gramineae) point to the extension of agro-pastoral activities during the later occupation phases. Specialists at the Autonomous University of Madrid conducted zooarchaeological studies on the assemblage of bones retrieved from the open-area excavations in 2006 (Macarro, Alario 2012.79-82). Their assessment illuminated consumption patterns at this settlement during phase III (conventionally dated to the $7^{\text {th }}-6^{\text {th }}$ centuries $\mathrm{BC}$ ): $80 \%$ are domestic animals, mostly adult sheep (Ovis aries), followed by pigs (Sus sp.), and cows (Bos taurus) used as draught animals, according to pathologies also attested in Soto de Medinilla (Romero Carnicero, Cubero Corpas 1999.179). The earliest hen bones have also been documented here.

Pottery comprises the most abundant archaeological material. The initial stages yield only hand-made pottery in the early Soto style (Tab. 1). Both coarse wares for storage and cooking and tableware feature prominently at Cerro de San Vicente. From the onset of the Iron Age c. 900/800 BC, fine wares for consuming foodstuffs were made to very high standards. Thus, EIA drinking vessels display homogeneous paste colours and extremely thin walls with intensely burnished smooth surfaces. These observations suggest the likely use of moulds, and perfect control of firing conditions within a sophisticated craftsmanship framework, which likely involved a certain degree of specialisation and technological innovation. Furthermore, these pottery repertoires in-

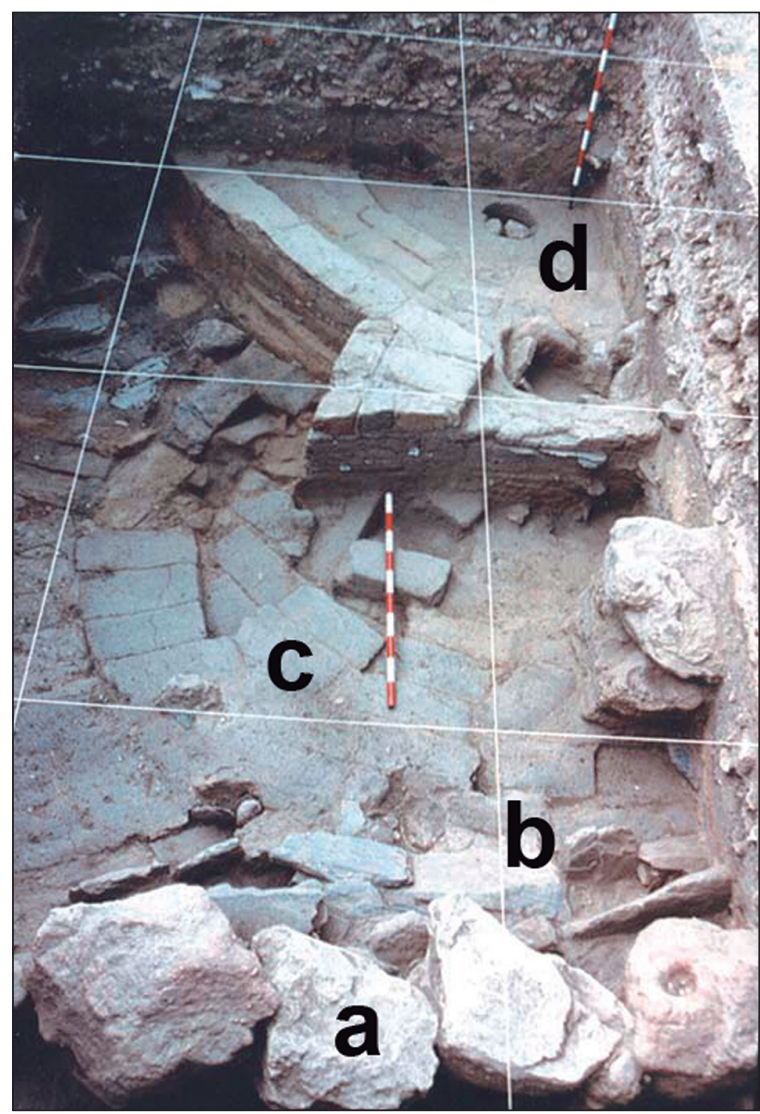

Fig. 8. Test-pit in 1990 showing a fence of boulders demarcating a compound (a), a drain pipe of slate slabs (b), an adobe-paved outdoor courtyard (c), and part of a roundhouse with multiple (17) soil layers (d).

dicate new ways of preparing and consuming food that are alien to this region, yet comparable to southern regions (Arnáiz, Fuente 2016).

The pottery has little decoration: sporadic geometric incisions and impressions in the upper part of vessels, and fingernail impressions on rims. This has made it difficult to construct accurate typological seriation (Romero Carnicero et al. 2008; Ruiz Zapatero 2009; Blanco García 2017), although several formal traits make it possible to trace the circulation of know-how and perhaps also potters. Thus, some types (biconical urns) indicate links to north-eastern Iberia and the Urnfield tradition, whereas the ubiquitous small carinated vessels clearly suggest southern Iberian and Levantine Iberian connections. Likewise, painted fine vessels in an Orientalising style (Fig. 10), allegedly originating in the Iberian southwest or 'Tartessian' area (Torres Ortiz 2002; Celestino, López Ruiz 2010), are index fossils of the EIA in central Iberia (Romero Carnicero et al. 2008). Bowls, cups and small pots exhibit geometric designs in diverse bichrome or polychrome combinations 


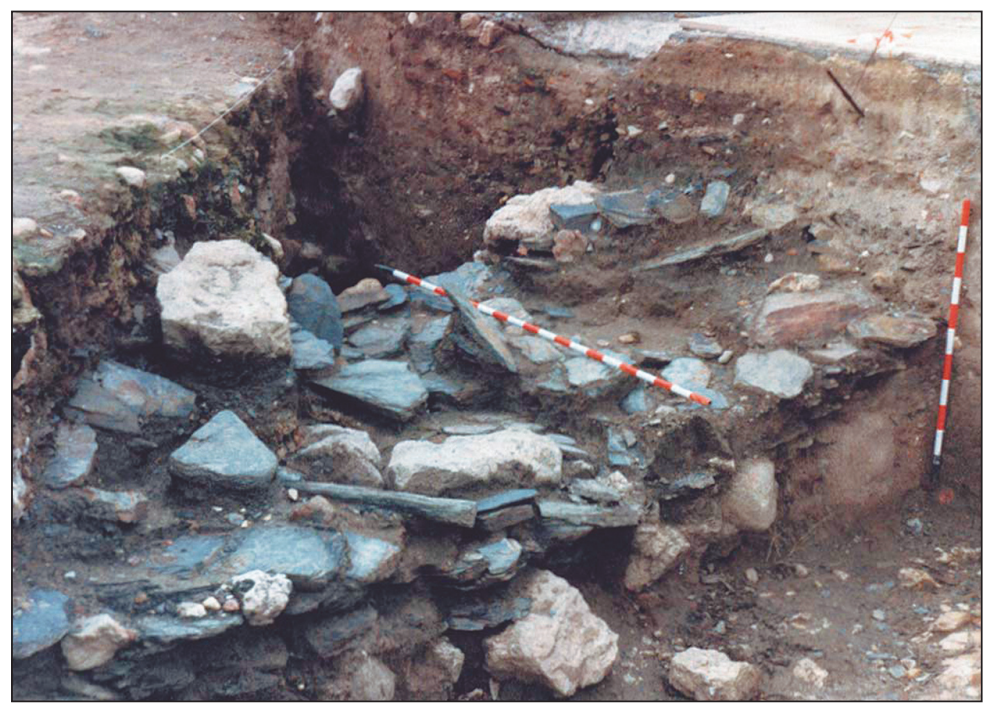

Fig. 9. The stone foundation of the village's earthen wall during rescue excavations in 1994-96 in the eastern sector.

to obtain eye-catching contrasting motifs (Fig. 10). Such coloured decorations were added after the firing stage of vessels. The upper phases also produced hand-made pottery in a later style, with abundant combed-impressed motifs, some of them also reproduced in the hand-made ceramics (Fig. 10). An outstanding discovery is a hollow hand-made terracotta object with intensely polished surfaces. It was found during the 2006 open-area excavation, lying upsidedown within the indoor collapsed filling (SU 517, phase II) of a rectangular adobe building. It vaguely resembles a bird-like shape, with a central vertical hole, a thin nozzle at one end (fragmented), and a thicker protuberance at the other end (also broken), and has four broken feet protruding at its base (Fig. 11). This is a unique item, with no clear parallels, or perhaps was a zoomorphic drinking vessel, a musical instrument - an idiophone (a rattle?) rather than an aerophone $^{2}$ - or even a perfume sprayer.

The inhabitants of Cerro de San Vicente used flint knapping, but tinbronze metallurgy is well attested, and this site has produced fragments of crucibles and abundant copperbased smelting by-products. Marks of metal knives are apparent on bones consumed at this village. Several imports are known at this site, such as simple and leaf-shaped double-spring fibulae (brooches), amorphous iron items and glass beads. The earliest wheel-thrown wares appeared in the $6^{\text {th }}$ century BC; they feature pale lightbrown pastes and some red painted lines; they probably originated in the Iberian southeast. The concentration of these exotic items in western Iberia suggests their probable diffusion from Atlantic and Mediterranean settings (Romero Carnicero et al. 2008; Delibes de Castro, Romero Carnicero 2011; Arnáiz, Fuente 2016).

\section{Discussion}

Village lifestyles spread across all Iberia from roughly similar dates (c. 900/800 BC) and adapted manifold socio-economic regional processes, ranging from egalitarian to increasingly statified organisations. In the long run, these ways of organising social life became extremely successful and resilient. Contrary to

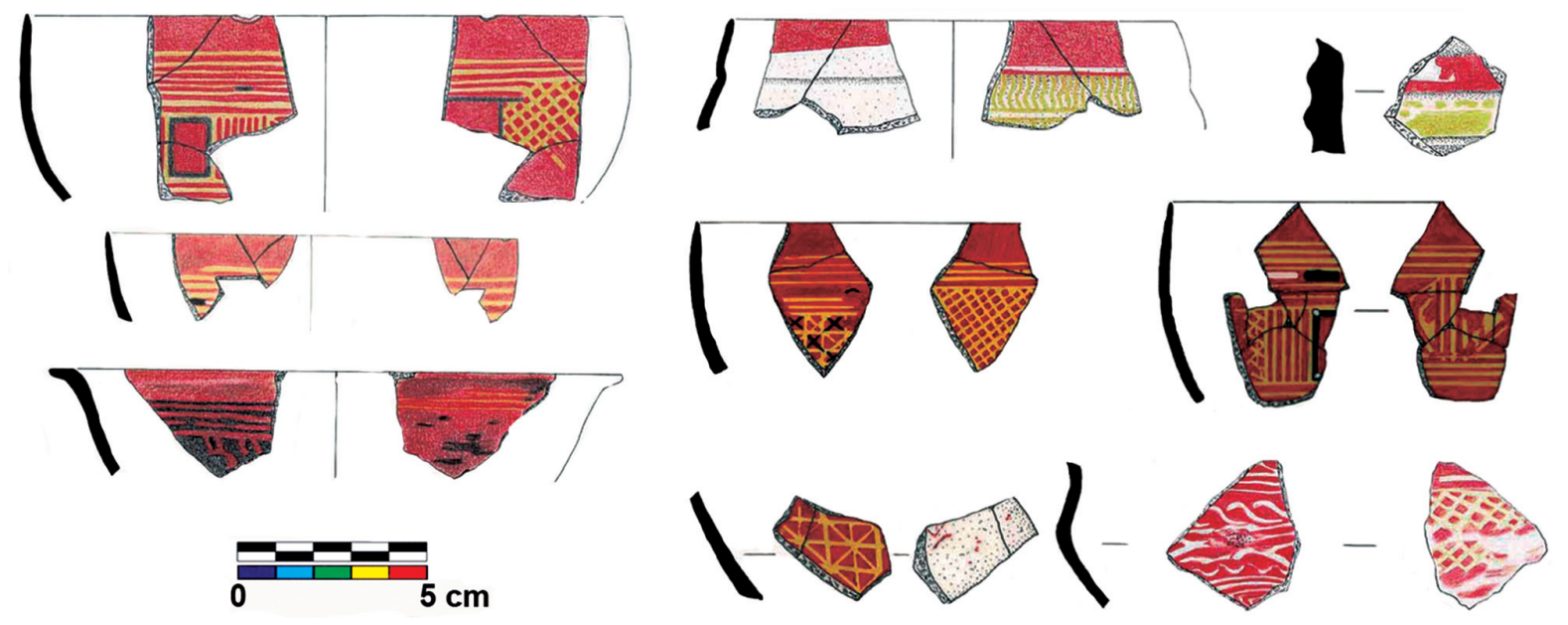

Fig. 10. Painted hand-made tableware in the Orientalising style.

2 It is not a lamp, as initially thought, since is very different from contemporary wheel-thrown pinched nozzle lamps and has no sooting marks. It resembles an ocarina, but lacks stops (holes for playing it) and the narrow and uneven chamber would resonate very poorly. 
previous attempts at permanent settlement in later prehistory, especially during the second millennium $\mathrm{BC}$, this date marked a point of no return in the ways of settling the Iberian landscapes.

Village-dwelling communities in central and northern Iberia accommodated diverse kinds of societies at different times. The available information suggests self-sufficient, small-scale agrarian groups composed of corporate kinship social units. The definitive sedentary nature of their customs is deduced from the massive character of their household archaeology, and from reliable palaeo-economic records. A communal ethos is apparent in the usual fortification of settlements with ditches or ramparts (e.g., González-Ruibal 2006-07.194; González García et al. 2011) and also in the homogeneity and regularity of modular architecture and building materials (Romero Carnicero et al. 2008.670). The absence of obvious social inequalities can be inferred from the comparable sizes of houses and overall similarities in their domestic inventories. Such features are in keeping with a peasant-like, undivided and roughly egalitarian social system (Esparza Arroyo 1995; 2011; Romero Carnicero et al. 2008; Ruiz Zapatero 2009; González García et al. 2011; Álvarez-Sanchís, RuizZapatero 2014). Nevertheless, a minute diachronic assessment of Cerro de San Vicente provides some valuable insights into the idiosyncratic materiality of these early villages in central Iberia. It also highlights some overlooked factors that might have contributed to these archaeological outcomes.

Excavations at this village have shed important light on the technological level and sophistication of its inhabitants. Domestic architecture exhibits an array of novel building techniques, especially adobe and ill-defined solid earthen walls. The advantages of such construction innovations are manifold: they guarantee long durability and fewer maintenance requirements than wattle-and-daub using widely available local materials; they facilitate thermoregulation, provide optimal hygiene and excellent insulation from weather and noise. These villages also succeeded in meeting basic needs and providing food for growing numbers of people. Contrary to millennial lifestyles, from 800 BC some nucleated habitats were very populous, and likely resulted from the aggregation of hitherto self-sufficient and scattered homesteads (Delibes de Castro, Romero Carnicero 2011; Ruiz Zapatero 2009; Álvarez-Sanchís, Ruiz-Zapatero 2014; Blanco García 2017). Thus, based on excavations and the available enclosed space (Fig. 4), Cerro de San Vicente was hypothe-

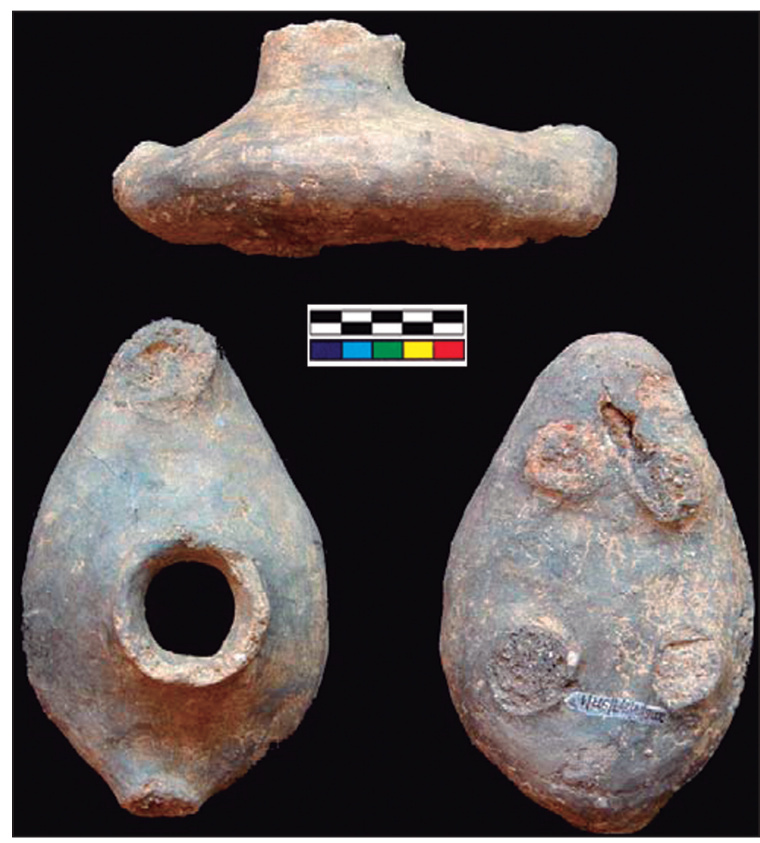

Fig. 11. Unique terracotta zoomorphic object of unknown function. Scale in cm.

tically home to about 60 small roundhouses, and if occupied by nuclear families of four members, this amounts to a minimum of 250 residents, a figure in accord with calculations for similar contemporary sites (González-Ruibal 2006/2007; Romero Carnicero et al. 2008). It is difficult to account for such numbers if the interregional movement of populations - a taboo concept for some scholars - is ruled out, inasmuch as Late Bronze Age landscapes in the region were really thinly populated (Esparza Arroyo 1995.137-139; Álvarez-Sanchís 2000.71-72; Romero Carnicero et al. 2008.652-657).

A contentious yet barely discussed issue in current Iron Age narratives is the very materiality of some sites as vertical accumulations up to $8 \mathrm{~m}$ high, comparable in many aspects to prehistoric tells from temperate Europe (Kienlin 2015). Iberian archaeological literature tacitly accepts that they are the unproblematic result of definitively sedentary lifestyles in relatively large agglomerations (by local standards). However, worldwide ethno-historical evidence shows that the nucleation of sedentary peoples does not necessarily entail thick and rich stratifications. Moreover, as occurred in other European cases, such as the Late Neolithic and Early/Middle Bronze Age tells in the Carpathian basin (Kienlin 2015), large multi-layer hilltop sites were rare occurrences in prehistoric landscapes dominated by small inconspicuous lowland sites. First-hand fieldwork at Cerro de San Vicente allows us to claim that its bulky and massive sediments resulted from specific cultur- 
al choices rather than being natural by-products of fully sedentary agglomerations. The formation dynamics of this village are mainly associated with customary ways of managing waste from daily chores and with particular ways of refurbishing and rebuilding houses, and these social practices led to the particular nature of these sites.

A long-held and deeply entrenched prejudice in European scholarship - hardly ever mentioned, with some exceptions (Webley 2007) - prompts archaeologists to presume that most Iron Age houses are akin to Pompeii-like scenarios, i.e. fortunate snapshots of everyday life ('systemic contexts') frozen at a discrete past instant (Schiffer 1987; LaMotta, Schiffer 1999). However, the foregoing review of the houses excavated so far at Cerro de San Vicente allows us to contest such a claim. The bulk of the house floors were unfurnished prior to abandonment, as was commonly the case everywhere (LaMotta, Schiffer 1999). Some buildings may have been partially ruined, yet even on these occasions, the trapped indoor items are not in accord with suddenly collapsed constructions. At this site, deserting a house most probably involved a pre-planned procedure and some cultural formality. Thus, some houses were deliberately set on fire, a cultural custom archaeologically traceable among other later European prehistoric tell communities (Stevanović 1997). In addition, some materials were indisputably placed after abandoning a house and before preparing the new home. Examples include: the zoomorphic terracotta item abandoned within a four-corner structure (Fig. 11), four suckling pigs deposited over the floor of a roundhouse, and caches of mud bricks filling empty roundhouses - some of them after burning (Fig. 7). Further deliberate under-floor deposits were probably connected with the cyclical rebuilding of houses, such as the interment of a neonate (Sánchez Alonso 2015).

These observations must be fully considered if we are to make reliable inferences about prehistoric social life. This is especially so when interpreting the contents of domestic buildings, since they will rarely be 'de facto refuse' or actual Pompeii-like scenarios of everyday activities (LaMotta, Schiffer 1999). At Cerro de San Vicente, both outdoor middens and indoor accumulations are deeply stratified, and postabandonment truncation is negligible, so that their multi-layer matrices allow fine-grained sequencing of materials. Moreover, contextual and stratigraphic associations are traceable between specific houses, annexed buildings and middens within fenced compounds. These types of spatial, temporal and contex- tual associations are invaluable for assessing such archaeological assemblages. In short, there is scope for addressing functional and social readings from this household archaeology, provided that we do so critically and with certain reservations.

A good starting point for a measured social characterisation of these communities is to assess the role of the domestic realm. Houses are pivotal in many societies (Joyce, Gillespie 2000), and acknowledging their relevance does not directly lead to envisaging any specific type of society. Yet we wonder whether there is room for illuminating the social mechanisms at work in these prehistoric groups from the seminal house society model (Joyce, Gillespie 2000; González-Ruibal 2006). We shall refer here to house societies in the sensible and restrictive sense posited by González-Ruibal (2006.145), drawing strictly on Levi-Strauss' original proposal. Within such a sociological framework, houses are basic and self-perpetuating corporate social units composed of co-resident household members who shared shelter, sustenance (land, cattle and equipment, i.e. 'economic capital') and immaterial wealth (rights and alliances, i.e. 'social and symbolic capital') and compete with each other to keep, enlarge and pass on their heritage undivided (Joyce, Gillespie 2000; González-Ruibal 2006; González-Ruibal, Ruiz-Gálvez 2016).

The foregoing review reveals that EIA houses matched several archaeological indicators considered by González-Ruibal and Ruiz-Gálvez (2016.387-388) as diagnostic traits of house societies: a) imperishable and massive building materials, with decorated walls and fireplaces that highlight the material investment in the domestic quarters; b) the potent symbolism of houses, suggested by the subsoil burial of children, the planned conflagration and closure of roundhouses with cached adobes, or the presence of likely cultic structures; c) the additive materiality of the dwellings, involving respect for, and incorporation of, successive accretions (foundations, soils, plaster coatings), which underscore their monumental appeal as a reservoir of architectural biographies and a deep concern with genealogical roots; and d) the perseverance of the earliest layouts for centuries, involving the persistent rebuilding of structures and the location of middens in the same spots, or the coincident orientation of house entrances and the superimposition of hearths, all indicating a strong corporate identity outlasting the lifespan of individuals through generations, as true memorials. All these commonalities at least allow us to desig- 
nate these communities as 'house-centric societies' (Gillespie 2007.27-29; González-Ruibal, Ruiz-Gálvez 2016.390). One major drawback remains to the applicability of the house society model to the EIA communities in central Iberia: their egalitarian and communal ethos, since they allegedly lacked strong internal inequality and competition among households.

Nonetheless, local forms of sociality within such villages were far from static and homogeneous. Indeed, diachronic approaches to their societal organisation (Romero Carnicero et al. 2008; Torres Rodríguez 2013; Álvarez-Sanchis, Ruiz-Zapatero 2014) indicate that some accrued increasingly internal disparity and struggle towards heterarchy, in spite of mechanisms against this trend (González García et al. 2011). Despite the narrow stratigraphic test pits often available (Ruiz Zapatero 2009), a great deal of the excavated villages yielded houses and smaller buildings arranged in no apparent order (Romero Carnicero et al. 2008; Blanco García 2017.662). However, the later phases at Cerro de San Vicente show neighbourhoods bounded by fences (Figs. 4, 8 ), as was also documented in open-area excavations at other villages (Macarro, Alario 2012.51-53; Misiego et al. 2013). Furthermore, the last occupation at the village of Soto de Medinilla (Delibes de Castro et al. 1995) features large storage jars in some houses, as well as porches, regarded as a device for displaying the wealth of some neighbours (Romero Carnicero, Cubero Corpas 1999.183-184; Romero Carnicero et al. 2008). These clusters and the very occurrence of storage vessels within certain domestic compounds tally well with the presence of houses displaying higher investments in architecture and exhibiting their wealth. Such observations open the door to envisaging them as 'great houses' within increasingly competitive and heterarchical organisations (González Ruibal, Ruiz-Gálvez 2016. 387, 397).

\section{Conclusions}

The excavations at Cerro de San Vicente offer a paradigmatic example of how our knowledge of later prehistoric European societies is still too patchy and how highly detailed fieldwork at selected sites can challenge scholarly ideas. A re-examination of diverse misguided claims may help more reliable and fruitful lines of inquiry to be considered. This has specifically been the case with approaches to tell-like settlements in central Iberia (e.g., Romero Carnicero et al. 2008; Blanco García 2017). The multi-layer village addressed here seems to be the unintended effect of many people disposing of their waste next to their houses, coupled with their preference for rebuilding houses on the same spot ( $c f$. Kienlin 2015). The additive accumulation of building foundations, hearths, mortar walls and soils was an iterative social practice that continued for centuries. These facts accord with a conscious attempt at perpetuating these accumulations and underpin the intention probably held by its inhabitants to continue the settlement indefinitely (Stevanovic 1997; Gillespie 2000.12-14).

In social terms, a fresh reading of the evidence can also be posited: among the studied prehistoric communities some became akin to the house society model (Gillespie 2000.27-29; González Ruibal 2006). As a general interpretive framework for the region, the accumulation of an agricultural surplus might have been facilitated by complex high-return agricultural systems and technological innovations (RuizGálvez 1994). These factors have been identified and discussed elsewhere (e.g., Fernández-Posse 1998; Romero Carnicero et al. 2008; Delibes de Castro, Romero Carnicero 2011) and are also apparent at Cerro de San Vicente, despite the incomplete publication of the respective evidence (Macarro, Alario 2012). Therefore, such agrarian accumulation was probably in operation in the Duero basin by the midfirst millennium BC. Over time, the domestic realm embodied the success of particular 'great houses', and provided the legitimisation for claiming prerogatives over other contending houses within local communities (Stevanović 1997.387-388). Social relations were progressively based on the transmission of land property rights by inheritance, and this led to an obsession with genealogical lines and social memory (Ruiz-Gálvez 1994; González Ruibal, RuizGálvez 2016). Prehistoric multi-layered sites are rich and promising test cases for this kind of account, yet research should also pay adequate attention to the smaller and numerous ill-defined farmsteads in their surroundings to avoid further biased accounts (Ruiz-Zapatero 2011.95).

The location of Cerro de San Vicente in central Iberia, far from the more permeable coastal settings entailed neither rusticity nor isolation in the material expressions of its inhabitants. This statement accords with previous claims about the existence of a sumptuous and cosmopolitan culture among some inner Iberian EIA local communities (Romero Carnicero et al. 2008.678). The excavations revealed technology, such as one of the oldest sewer pipes known in 
northern Iberia or building techniques that endured up to modern times. The earliest villages in the EIA central Iberia are characterised by avant-garde earth building techniques, exotic domestic animals and novel technologies capable of sustaining growing populations, a renovated material culture and contrasting ways of consuming food and enacting rituals (Álvarez-Sanchis 2000; Torres Ortiz 2002). These novelties taken together make more sense if exchange, connectivity and demic movement between Atlantic and Mediterranean Iberian areas where Phoenicians were established are fully taken into account. The means of dispersal and adoption of such innovations and the biological contribution of southern immigrant people will be hot topics in the near future. Illuminating such multifaceted aspects will require clearly formulated questions and sciencebased enquiry to start disentangling the onset of the Iron Age in Iberia from fresh perspectives.

\section{ACKNOWLEDGEMENTS}

Dr. Sarah Barber, Dr. Guy David Hepp and Prof. Richard Dumbrill suggested some ideas to interpret the rare terracotta object. An anonymous reviewer improved an early draft with her/his insightful suggestions. The excavations reported here, as well as the current research project on Cerro de San Vicente (http://www.salamanca.es/cerro/) are funded by the Autonomous Government of Castile and Leon and the Council of Salamanca.

\section{$\therefore$}

\section{References}

Almagro-Gorbea M. 1995. From hillforts to oppida in 'Celtic' Iberia. In B. Cunliffe, S. Keay (eds.), Social Complexity and the Development of Towns in Iberia: From the Copper Age to the Second Century A.D. British Academy and Oxford University Press. Oxford: 175-207.

(ed.) 2014. Iberia. Protohistory of the Far West of Europe: From Neolithic to Roman Conquest. Universidad de Burgos. Burgos.

Álvarez-Sanchís J. R. 2000. The Iron Age in Western Spain (800 BC-AD 50): an overview. Oxford Journal of Archaeology 19(1): 65-89. http://dx.doi.org/10.1111/1468-0092. 00100

Álvarez-Sanchís J. R., Ruiz-Zapatero G. 2014. The Emergence of Urbanism in Early Iron Age Central Iberia. In M. Fernández-Gotz, H. Wendling and K. Winger (eds.), Paths to Complexity. Centralisation and Urbanism in Iron Age Europe. Oxbow. Oxford: 204-213.

Arnáiz M. A., Fuente I. 2016. El horno de origen oriental procedente del séptimo nivel de hábitat de El Soto de Medinilla (s. VII A.C.). Zephyrus 77(1): 99-117.

Belarte M. C. 2002. La Construcció amb terra a la protohistòria. Societat Catalana d'Arqueologia. Barcelona.

Benet Jordana N. 2001. La ciudad de Salamanca. De su formación a la Repoblación. In Salamanca Ciudad Europea de la Cultura 2002. Consorcio Salamanca 2002. Salamanca: 15-43.
Blanco García J. F. 2017. Los pueblos prerromanos del interior peninsular y los territorios atlánticos. In S. Celestino Pérez (ed.), Historia de España II. La Protohistoria en la península Ibérica. Istmo. Madrid: 647-811.

Celestino S., López Ruiz C. 2016. Tartessos and the Phoenicians in Iberia. Oxford University Press. Oxford.

Delibes de Castro G., Romero Carnicero F. and Ramírez Ramírez M. L. 1995. El poblado 'céltico' de El Soto de Medinilla (Valladolid). In G. Delibes de Castro, F. Romero Carnicero and A. Morales (eds.). Arqueología y medio ambiente. El primer milenio a. C. en el Duero Medio. Junta de Castilla y León. Valladolid: 149-177.

Delibes de Castro G., Romero Carnicero F. 2011. La plena colonización agraria del Valle Medio del Duero. In J. R. Álvarez-Sanchís, A. Jimeno and G. Ruiz Zapatero (eds.), Aldeas y ciudades en el primer milenio a. C. La Meseta Norte y los orígenes del urbanismo. Complutum 22(2). Universidad Complutente de Madrid. Madrid: 49-94.

Esparza Arroyo A. 1995. La Primera Edad del Hierro. In J. C. Alba (ed.), Historia de Zamora, I, De los Orígenes al Final del Medievo. Diputación de Zamora. Zamora: 101150 .

2011. Los castros del oeste de la Meseta. In J. R. Álvarez-Sanchís, A. Jimeno and G. Ruiz Zapatero (eds.), Aldeas y ciudades en el primer milenio a. C. La Meseta Norte y los orígenes del urbanismo. Complutum 22(2). Universidad Complutente de Madrid. Madrid: 11-47. 
Esparza Arroyo A., Velasco Vázquez J. and Celis Sánchez J. 2016. Notas sobre la fase Soto Formativo en el poblado de los Cuestos de la Estación (Benavente, Zamora). Boletín del Seminario de Estudios de Arte y Arqueología LXXXII: 63-85.

Fernández-Posse M. D. 1998. La investigación protohistórica en la Meseta y Galicia. Síntesis. Madrid.

Galán Domingo E., Ruiz-Gálvez M. 2001. Rutas ganaderas, transterminancia y caminos antiguos. El caso del Occidente peninsular entre el Calcolítico y la Edad del Hierro. In J. Gómez-Pantoja (ed.), Los rebaños de Gerión: pastores $y$ trashumancia en Iberia antigua y medieval. Casa de Velázquez. Madrid: 263-278.

Gillespie S. D. 2000. Beyond Kinship: An Introduction. In R. A. Joyce, S. D. Gillespie (eds.), Beyond Kinship. Social and Material Reproduction in House Societies. University of Pennsylvania Press. Philadelphia: 1-21.

González García F. J., Parcero-Oubiña C. and Ayán Vila X. 2011. Iron Age societies against the State: an account of the emergence of the Iron Age in North-western Iberia. In T. Moore, X-L. Armada (eds.), Atlantic Europe in the First Millenium BC: Crossing the Divide. Oxford University Press. 0xford: 285-301.

González-Ruibal A. 2006. House societies vs. kinship-based societies: An archaeological case from Iron Age Europe. Journal of Anthropological Archaeology 25: 144-173. http://dx.doi.org/10.1016/j.jaa.2005.09.002

2006/2007. Galaicos. Poder y Comunidad en el Nordeste de la Península Ibérica (1200 a.C.-50 d.C). Museo Arqueolóxico e Histórico de San Antón. A Coruña.

González-Ruibal A., Ruiz-Gálvez M. 2016. House Societies in the Ancient Mediterranean (2000-500 BC). Journal of World Prehistory 19: 383-437.

Hamilton W. D., Haselgrove C. and Gosden C. 2015. The impact of Bayesian chronologies on the British Iron Age. World Archaeology 47(4): 642-660. http://dx.doi.org/10. 1007/s10963-016-9098-8

Haselgrove C., Pope R. (eds.) 2007. The Earlier Iron Age in Britain and the near continent. Oxbow. Oxford.

Jaquin P. A., Augarde C. and Gerrard C. M. 2008. A chronological description of the spatial development of rammed earth techniques. International Journal of Architectural Heritage 2(4): 377-400.

Joyce R. A., Gillespie S. D. (eds.) 2000. Beyond Kinship. Social and Material Reproduction in House Societies. University of Pennsylvania Press. Philadelphia.
Kienlin T. L. 2015. Bronze Age tell communities in context. An exploration into culture, society and the study of European Prehistory. Archaeopress. Oxford.

Kristiansen K. 1998. Europe before History. Cambridge University Press. Cambridge.

LaMotta V., Schiffer M. B. 1999. Formation processes of house floor assemblages. In P. Allison (ed.), The Archaeology of Household Activities. Routledge. London: 19-29.

Macarro C., Alario C. 2012. Los Orígenes de Salamanca. El poblado protohistórico del Cerro de San Vicente. Centro de Estudios Salmantinos. Salamanca.

Maluquer de Motes J. 1951. De la Salamanca Primitiva. Zephyrus II: 61-72.

Misiego J. C. and 13 co-authors. 2013. Las excavaciones arqueológicas en el yacimiento de 'La Corona/El Pesadero' en Manganeses de la Polvorosa. Junta de Castilla y León. Zamora.

Moore T., Armada X.-L. 2011. Crossing the Divide: Opening a Dialogue on Approaches to Western European First Millennium BC Studies. In T. Moore, X.-L. Armada (eds.), Atlantic Europe in the First Millennium BC. Crossing the Divide. Oxford University Press. Oxford: 3-77.

Parcero C. 2003. Looking forward in anger: Social and political transformations in the Iron Age of the north-western Iberian peninsula. European Journal of Archaeology 6 (3): 267-299. http://dx.doi.org/10.1177/146195710300 600304

Reimer P. J. and 29 co-authors. 2013. IntCal13 and Marine13 radiocarbon age calibration curves $0-50,000$ years cal BP. Radiocarbon 55(4): 1869-1887. http://dx.doi. org/10.2458/azu_js_rc.55.16947

Rodríguez Díaz A. (ed.) 2004. El Edificio protohistórico de la 'La Mata' (Campanario, Badajoz) y su estudio territorial. Universidad de Extremadura. Cáceres.

Roldán Hervás J. M. 2007. El Camino de la Plata: iter o negotium. Gerión 27(extra 1): 323-340.

Romero Carnicero F., Cubero Corpas C. 1999. Agricultura y recolección en la cultura del Soto (Primera Edad del Hierro en el valle medio del Duero). In R. Buxó, E. Pons (eds.), Els productes alimentaris d'origen vegetal a l'Etat del Ferro de l'Europa Occidental: de la producció al consum. Museu d'Arqueologia de Catalunya. Girona: 169187.

Romero Carnicero F., Sanz Mínguez C. and Álvarez-Sanchís J. R. 2008. El primer milenio A.C. en las tierras del 
interior peninsular. In F. Gracia (ed.), De Iberia a Hispania. Ariel. Barcelona: 649-732.

Ruiz-Gálvez M. L. 1994. The bartered bride: Goldwork, inheritance and agriculture in the later prehistory of the Iberian Peninsula. Journal of European Archaeology 2(1): 50-81. http://dx.doi.org/10.1179/096576694800719229

Ruiz Zapatero G. 2009. Casas, comunidades y tipos de sociedad en el área céltica peninsular. In M. C. Belarte Franco (ed.), L'espai domèsic i la organització de la societat a la protohistòria de la Mediterrània occidental (1er millenni a.C.). Arqueomediterrània. Universitat de Barcelona: 225-243.

2011. Settlement and landscape in Iron Age Europe: archaeological mainstreams and minorities. In T. Moore, X-L. Armada (eds.), Atlantic Europe in the First Millennium BC: Crossing the divide. Oxford University Press. Oxford: 81-108.

Sánchez Alonso E. 2015. Inhumaciones infantiles en ambientes domésticos de la Edad del Hierro en el valle del Duero. Unpublished BA dissertation. University of Valladolid. Valladolid. http://uvadoc.uva.es/handle/10324/164 09
Shillito L.-M. 2017. Multivocality and multiproxy approaches to the use of space: lessons from 25 years of research at Çatalhöyük. World Archaeology 49: 237-259. http:// dx.doi.org/10.1080/00438243.2016.1271351

Schiffer M. B. 1987. Formation Processes of the Archaeologic Record. University of Utah Press. Salt Lake City.

Stevanović M. 1997. The age of clay: The social dynamics of house destruction. Journal of Anthropological Archaeology 16: 334-395. http://dx.doi.org/10.1006/jaar.1997. 0310

Torres Ortiz M. 2002. Tartessos. Real Academia de la Historia. Madrid.

Torres Rodríguez J. de 2013. La tierra sin límites. Territorio, sociedad e identidades en el valle medio del Tajo (s. IX-I a.C.). Museo Arqueológico Regional. Madrid.

Webley L. 2007. Using and Abandoning Roundhouses: A Reinterpretation of the Evidence from Late Bronze AgeEarly Iron Age Southern England. Oxford Journal of Archaeology 26(2): 127-144. http://dx.doi.org/10.1111/j. 1468-0092.2007.00277.x

\section{back to contents}

